\title{
Drinking Water Quality Scenario at Kallam's Green City, Ameenabad, Guntur District, Andhra Pradesh
}

\author{
M. Satish Kumar, K. Navya Sri, U. V. Koteswara Rao, P. Deekshitha, SK. Nadeem
}

\begin{abstract}
Groundwater is the basic and prime component to be considered, as it is directly linked with the developmental activities of any area in the whole world. In the current scenario the availability of groundwater for future generation is biggest problematic question to be asked by every nation. In the actual scenario its availability is minimum and the dependency on groundwater is maximum to meet all the requirements of water demand and this situation has been continuing years long due to excessive and abnormal increments in the growth of population [6] and it becomes more worse especially in the developing countries as well as in the urban areas [8], at one side the population is increasing and at the same time the availability of natural resources like soil, clean air and portable water keep on polluting due to the natural activities like floods, droughts etc apart from manmade activities in order to improving living standards. Water in the aquifers of earth crust depends on the soil porosity, pore size and the geological conditions [10] with respect to the holding capacity of water, even though groundwater is the source to consider as one of the rechargeable resource but it is completely depends on the measures to adopt for recharging such as recharging pits and the average rainfall of that particular area. In this study all the parameters of IS drinking water quality standards 10500 - 2012 are examined for the collected groundwater samples of three cycles and the average values of three cycles were considered as final results. The results were compared to find out the existed water quality scenario at the study area.
\end{abstract}

Key words: Aquifers, Drinking water, Groundwater, Porosity, Population.

\section{INTRODUCTION}

Water is the key component for the survival of any living organism on the earth which is available both in the form of surface water [7] and groundwater, even though surface water availability is much more than the groundwater it is not feasible to drink as major part of its content is existed in the form of oceans which not suitable for human consumption point of view [9] so the groundwater is the only alternative at any area which is available in the form of aquifers from shallow to deeper part of earth crust.

Revised Manuscript Received on February 05, 2020.

* Correspondence Author

Dr. Satish Kumar Moparthi*, professor, Dapartment of Civil Engineering, Kallam Harandha Reddy Institute of Technology, Guntur, Andhra Pradesh, India.

K. Navya sri, Dapartment of Civil Engineering, Kallam Harandha Reddy Institute of Technology, Guntur, Andhra Pradesh, India.

U. V. Koteswara Rao, Dapartment of Civil Engineering, Kallam Harandha Reddy Institute of Technology, Guntur, Andhra Pradesh, India.

P. Deekshiha, Dapartment of Civil Engineering, Kallam Harandha Reddy Institute of Technology, Guntur, Andhra Pradesh, India.

SK. Nadeem, Dapartment of Civil Engineering, Kallam Harandha Reddy Institute of Technology, Guntur, Andhra Pradesh, India.

(C) The Authors. Published by Blue Eyes Intelligence Engineering and Sciences Publication (BEIESP). This is an open access article under the CC BY-NC-ND license (http://creativecommons.org/licenses/by-nc-nd/4.0/)
In particular the flow and the yield of groundwater is good and maximum at shallow aquifers lies below the sub soil than the aquifers lies in the deeper ground.

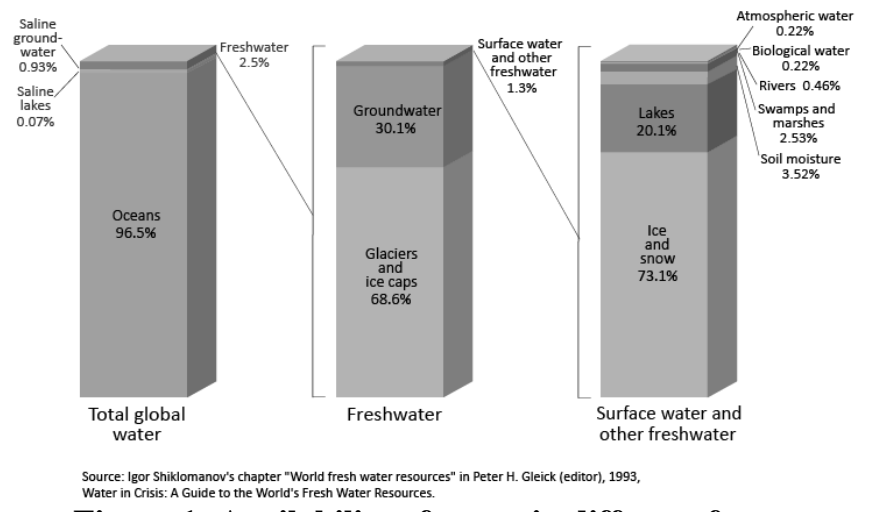

Figure 1: Availability of water in different forms

The yield of aquifers majorly depends on the pore sizes of the associated soil and their permeability factor for recharging process. The water quantity of aquifers can be measured approximately by the water levels in the nearby conventional wells.

Groundwater is portable for all the activities including domestic needs than the surface water with minimum treatment as the chance of contamination for groundwater is minimum than the surface water, but now a days the chances of water contamination is keep on increasing to the groundwater also as the lifting of water is increasing gradually year by year to meet the requirements of all the people as well as to all the developmental activities taking place which in turn leads to underground water contamination [11] especially in fresh water aquifers it is more and reduces the yield of fresh water, when the same situation of over lifting water continues, the pressure on soil damages the pore size and structure which leads to deformation of water holding capacity of soil. The present study was carried out in Kallam's Green city, ameenabad, which is a lush green venture to find out the groundwater quality. Sterilized labelled glass bottles were used to collect the water samples. All the tests were conducted with standard analytical methods [4] then the results were compared with IS 10500 - 2012 drinking water quality parameters.

\section{ABOUT THE STUDY AREA}

Kallam's Green city is located in the coordinates of $16.2987^{\circ}$ $\mathrm{N}, 80.2997^{\circ} \mathrm{E}$, at Ameenabad village in Phirangipuram mandalam of Guntur district, Andhra Pradesh. 
The location is very near to capital city of Andhra Pradesh as well as very much easy and near to connect Hyderabad Guntur and Kurnool - Guntur junction.
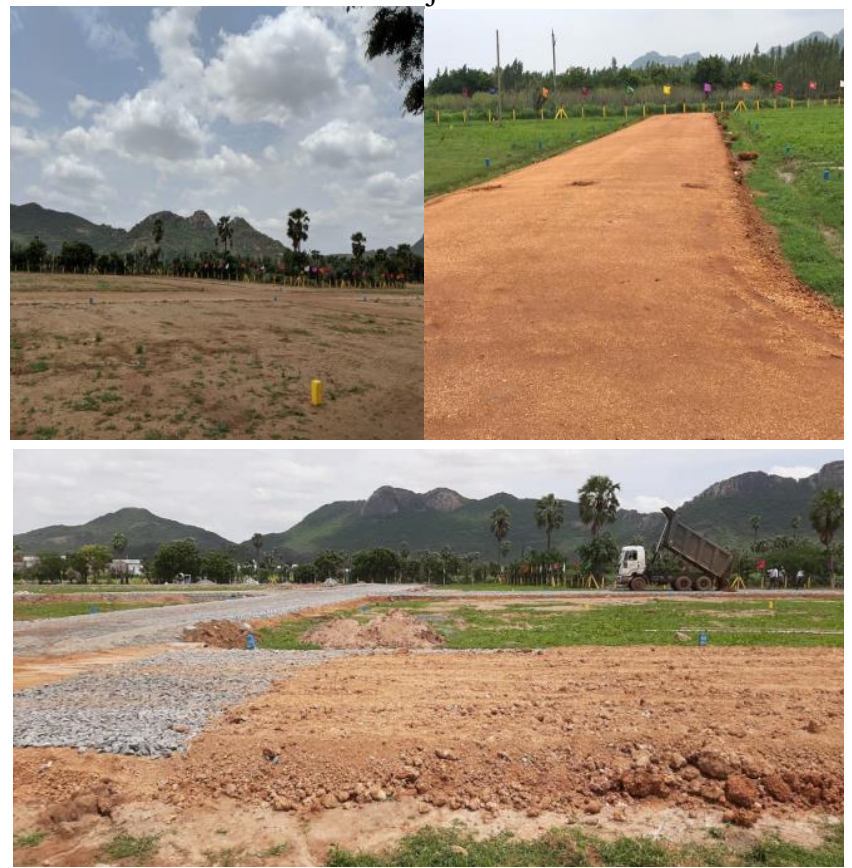

Figure 2: Location of the study area

\section{OBJECTIVES}

1. Location identity for sampling in the study area.

2. Selection of the standard Procedure to conduct tests [2] for all the parameters

3. Correlation of all the parameter of drinking water quality with IS 10500-2012 drinking water quality standards.

\section{METHODOLOGY}

\section{IV.I Sampling Location:}

1. Three samples were collected for three cycles during the period of three months study period.

2. Clean sterilizes bottles were used to collect the water samples from the bore hole

3. All the samples collected bottles are labelled

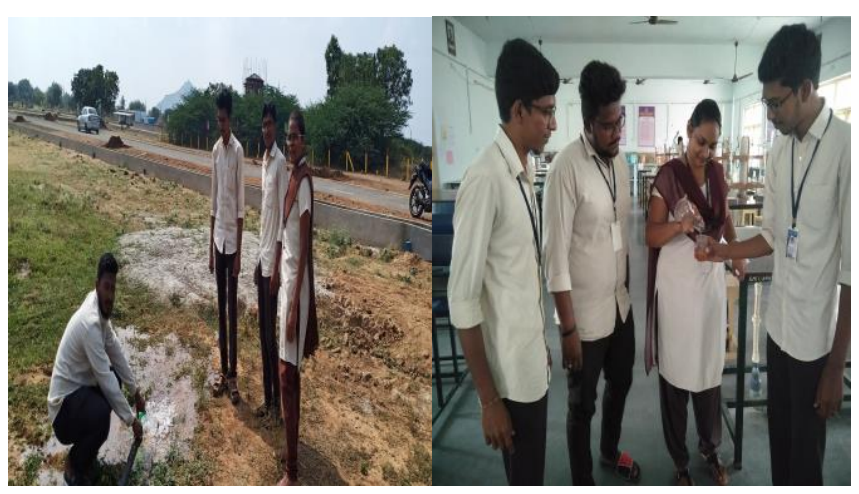

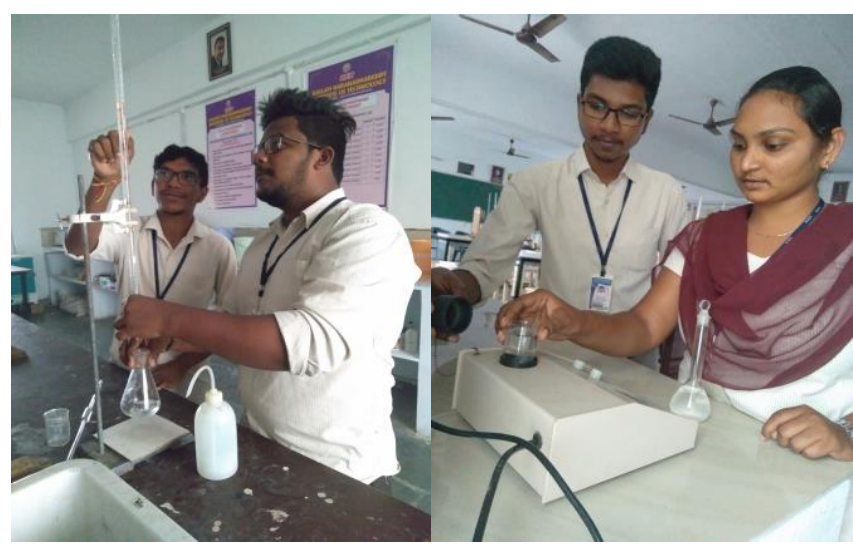

Figure 3: Sample collection and analysis

IV.II Water quality Analysis:

1. Water quality analysis was carried out for three times for three cycles.

2. Tests were conducted with standard and suitable analytical methods [5]

3. The average of three months values were considered as final result for water quality at study area.

4. The final obtained results were correlated with standards of drinking water quality IS 10500-2012 to find out the actual existed scenario of the water quality

5. Based on the correlation the suitability of water for drinking and domestic consumption will be evaluated.

Table 1 Groundwater quality at study area

\begin{tabular}{|c|c|c|}
\hline S.NO & PARAMETER & VALUES \\
\hline 1 & $\mathrm{P}^{\mathrm{H}}$ & 6.83 \\
\hline 2 & $\mathrm{EC}$ & $240 \mathrm{mmho} / \mathrm{cm}$ \\
\hline 3 & Colour & 4 Hazens \\
\hline 4 & Odour & Unobjectionable \\
\hline 5 & Turbidity & $1 \mathrm{NTU}$ \\
\hline 6 & Total Hardness & $185 \mathrm{mg} / \mathrm{L}$ \\
\hline 7 & Iron & $0.29 \mathrm{mg} / \mathrm{L}$ \\
\hline 8 & Chlorides & $230.48 \mathrm{mg} / \mathrm{L}$ \\
\hline 9 & $\begin{array}{l}\text { Residual free } \\
\text { chlorine }\end{array}$ & 0.02 \\
\hline 10 & $\begin{array}{l}\text { Total Dissolved } \\
\text { solids }\end{array}$ & $134 \mathrm{mg} / \mathrm{L}$ \\
\hline 11 & Copper & $0.04 \mathrm{mg} / \mathrm{L}$ \\
\hline 12 & Manganese & $0.1 \mathrm{mg} / \mathrm{L}$ \\
\hline 13 & Sulphates & 196.mg/L \\
\hline 14 & Nitrates & $35 \mathrm{mg} / \mathrm{L}$ \\
\hline 15 & Fluoride & $0.7 \mathrm{mg} / \mathrm{L}$ \\
\hline 16 & Total alkalinity & $195.12 \mathrm{mg} / \mathrm{L}$ \\
\hline 17 & Boron & $0.9 \mathrm{mg} / \mathrm{L}$ \\
\hline 18 & $\mathrm{DO}$ & $3.2 \mathrm{mg} / \mathrm{L}$ \\
\hline 19 & COD & $9.6 \mathrm{mg} / \mathrm{L}$ \\
\hline 20 & BOD & $4.9 \mathrm{mg} / \mathrm{L}$ \\
\hline 21 & Carbonates & $0.49 \mathrm{meq} / \mathrm{l}$ \\
\hline 22 & Bicarbonates & $4.12 \mathrm{meq} / \mathrm{l}$ \\
\hline 23 & Aluminium & $0.01 \mathrm{mg} / \mathrm{L}$ \\
\hline
\end{tabular}




\begin{tabular}{|c|c|c|}
\hline 24 & $\begin{array}{c}\text { Total Suspended } \\
\text { Solids }\end{array}$ & $196 \mathrm{mg} / \mathrm{L}$ \\
\hline 25 & Sodium & $85 \mathrm{mg} / \mathrm{L}$ \\
\hline
\end{tabular}

\section{RESULTS AND DISCUSSIONS}

\begin{tabular}{|c|l|l|}
\hline S.NO & \multicolumn{1}{|c|}{ PARAMETER } & \multicolumn{1}{c|}{ EXPLANATION } \\
\hline 1 & $\mathrm{P}^{\mathrm{H}}$ & $\begin{array}{l}\text { The value of } \mathrm{P}^{\mathrm{H}} \text { is } 6.83 \text { which is within the acceptable limits when compared with IS } \\
10500 \text { - } 2012 \text { drinking water quality standards at study area. }\end{array}$ \\
\hline 2 & Colour & $\begin{array}{l}\text { The result of colour indicates as } 4 \text { on Hazen units which is within the acceptable range as } \\
\text { per the standards of IS } 10500 \text { - 2012 }\end{array}$ \\
\hline 3 & Odour & $\begin{array}{l}\text { It is unobjectionable for consumption point of view and the result also unobjectionable so } \\
\text { it is within the acceptability limits. }\end{array}$ \\
\hline 4 & Total Hardness & $\begin{array}{l}\text { Total hardness of the water must be within the limits of 200mg/ here the results were } \\
\text { indicating as } 185 \text { mg/l which is within the acceptable range. }\end{array}$ \\
\hline 5 & Total Dissolved solids & $\begin{array}{l}\text { It is one of the important parameter to consider as per the result obtained it is within the } \\
\text { acceptable range when it is compared with IS 10500-2012 standards for drinking }\end{array}$ \\
\hline 6 & $\begin{array}{l}\text { Nitrates also important to be considered for domestic consumption point of view as per the } \\
\text { results it is within the acceptability range when it is correlated with drinking water quality } \\
\text { standards of IS 10500-2012 }\end{array}$ \\
\hline 7 & $\begin{array}{l}\text { All the remaining parameters also lies within the acceptable limits when correlate with IS drinking water quality } \\
\text { standards of 10500 - 2012 }\end{array}$ \\
\hline
\end{tabular}

\section{CONCLUSIONS}

1. Groundwater quality is always dynamic as it depends on the local geological conditions, climatic conditions along with the developmental activities taking place in the locality where human interference is more with respect to groundwater [1]

2. In the present study as per the results obtained the water quality is within the acceptable limits as per the drinking water quality standards of IS 10500-2012.

3. Groundwater in the study area is recommendable for all domestic and other activities at study area

4. Groundwater is limited natural resource gifted to the human kind so there should be a proper precautions on handling of groundwater [3]

5. Percolation pits must be made mandate for all the upcoming newly constructing buildings to recharge the groundwater for promoting sustainable development with respect to groundwater quality and quantity at study area.

\section{REFERENCES}

1. Statistical modelling of groundwater for environmental sustainability by M. Satish Kumar, Ambati Dattatreya Kumar, G. Venu Ratna Kumari, P.Siva Sankar and A.Vijaya Bhaskar Reddy published in International Journal of Innovative technology and exploring Engineering, Volume No: 9. Issue No: 4, February 2020, pp 461-464, ISSN: 2278-3075.

2. Comprehensive index of groundwater prospects by using standard protocols - A model study, M.Satish Kumar, M.V Raju and Hepsibapalivela in International Journal of Civil Engineering and Technology, Volume No: 8. Issue No: 05, 2017 pp 521 - 526. ISSN: 0976-6316
3. Text book on Environmental Engineering-I: Principles of water supply engineering by Satish Kumar Moparhi published by Lambert academic publishing with ISBN 978-613-7-45184-7.

4. Chemical Analysis of Water and Soil, Third Edition, by Dr. KVSG Murali Krishna.

5. Groundwater Quality at Down Stream Area of River Basin by using Geospatial Engineering by M. Satish Kumar, G. Venu Ratna Kumari, Ambati Dattatreya Kumar, and M.V Raju published in International Journal of Innovative technology and exploring Engineering, Volume No: 9. Issue No: , January 2020, pp 1236 - 1240, ISSN: 2278-3075.

6. Mapping and modelling of groundwater pattern using geo spatial technology, M.Satish Kumar, M.V Raju, G.VenuRatnakumari and S.Rameshbabuin International Journal of Civil Engineering and Technology, Volume No: 9, Issue No: 09, 2017, pp 110 - 115, ISSN: 0976-6316.

7. Interpretation and correlative study of water simulation in surface water bodies: , by M.Satish Kumar, M.V Raju, S.Ramesh babu and M.saiva jagadesh kumar published in International Journal of Civil Engineering and Technology, Volume No: 8. Issue No:5, May 2017, pp 1206 - 1211, ISSN: 0976-6308.

8. Urban water quality scenario by using geospatial engineering by $\mathrm{M}$. Satish Kumar, , G. Venu Ratna Kumari, Ambati Dattatreya Kumar and P.Srinivasa Rao published in International Journal of Innovative technology and exploring Engineering, Volume No: 9. Issue No:3, January 2020, pp 200- 205, ISSN: 2278-3075.

9. Water quality scenario in urban polluted lakes : A model study by M.Satish Kumar ,M.V Raju, Hepsiba palivela and G.Venu Ratna kumari published in International Journal of Civil Engineering and Technology, Volume No: 8. Issue No: 5, May 2017 pp 297 to 302., ISSN:0976-6316.

10. Impact of limestone on groundwater and soil by M. Satish Kumar, P. Srinivasa Rao, G. Venu Ratna Kumari and Ambati Dattatreya Kumar published in International Journal of Recent Technology and Engineering, Volume No: 8. Issue No: 5, January 2020, pp 1101 - 1104, ISSN: 2277-3878.

11. Textbook on Irrigation Engineering: Conservation of soil and water by Satish kumar Moparthi published by Lambert academic publishing with ISBN:978-620-0-32116-9 


\section{AUTHORSPROFILE}

Dr. Satish Kumar Moparthi, is the professor of Civil Engineering in Kallam Harandha Reddy Institute of Technology, Guntur, Andhra Pradesh, India. He has published two text books and he has more than 45 International journals in the field of Civil Engineering. He got sanctioned grant from Science and Engineering Research Board, Government of India. Department of Science and Technology,

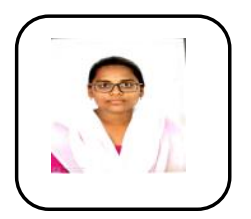

K. Navya Sri, is the IV Year B.Tech Civil Engineering student in Kallam Harandha Reddy Institute of Technology, Guntur, Andhra Pradesh, India.

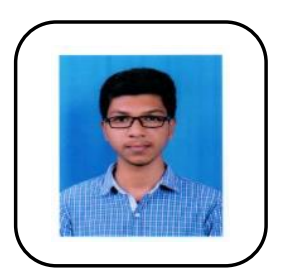

U. V. Koteswara Rao, is the IV Year B.Tech Civil Engineering student in Kallam Harandha Reddy Institute of Technology, Guntur, Andhra Pradesh, India.

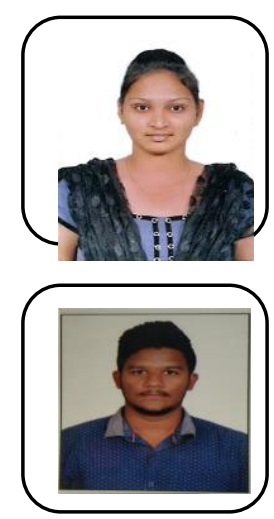

P. Deekshiha, is the IV Year B.Tech Civil Engineering student in Kallam Harandha Reddy Institute of Technology, Guntur, Andhra Pradesh, India.

SK. Nadeem, is the IV Year B.Tech Civil Engineering student in Kallam Harandha Reddy Institute of Technology, Guntur, Andhra Pradesh, India. 